\title{
A questionnaire based institutional assessment of 'knowledge', 'attitude' and 'practice' about bio-ethics in clinical research among postgraduate residents
}

\author{
Md Mohsin Ahmed*, Amreen Saba
}

Department of Pharmacology, KBN university- Faculty of Medical Sciences (formerly known as KBN Institute of Medical Sciences), Kalaburagi, Karnataka, India

Received: 15 July 2021

Revised: 21 July 2021

Accepted: 22 July 2021

\section{*Correspondence:}

Dr. Md Mohsin Ahmed,

Email: mohammed.mohsin.ahmed@gmail.com

Copyright: ( ) the author(s), publisher and licensee Medip Academy. This is an open-access article distributed under the terms of the Creative Commons Attribution Non-Commercial License, which permits unrestricted non-commercial use, distribution, and reproduction in any medium, provided the original work is properly cited.

\begin{abstract}
Background: Research ethics govern the standards of conduct for scientific researchers. Post graduate residents are one of the key stakeholders in clinical research. Therefore, the present study is designed to assess the Knowledge, Attitude and Practice about bio-ethics in clinical research among post-graduate residents.

Methods: A self-administered pretested questionnaire was given to 40 students selected on the basis of convenience sampling. The questionnaire consists of questions related to knowledge and attitude toward principles and practice of bioethics in clinical research, informed consent, and role of the ethics committee in the institution. Descriptive statistics was used to analyse the results.

Results: $70 \%$ of the students have formally taken Hippocratic Oath. Knowledge, attitude, and practice regarding Institutional Ethics Committee, and informed consent were more among final year students when compared to their juniors. Source of knowledge of bioethics were multiple. Department lectures were not a preferred mode of learning.

Conclusions: There is an urgent need to include practical education of ethics to bridge the gap in the knowledge, attitude, and practices regarding ethics in clinical practice and research.
\end{abstract}

Keywords: Institutional ethics committee, Hippocratic oath, Bioethics, Informed consent

\section{INTRODUCTION}

The concept of ethics and psychology is mostly related to human behaviour. Psychology explains the actual behaviour of the man whereas ethics explains how they tend to behave. The main parts of ethics includes statements encircle the rules that a person can apply in his life. It specifies professional protocols or conduct between professional groups and stresses universal moral principle. ${ }^{1}$ The Hippocratic Oath (which forms the moral ground of clinical practice) is currently viewed logically. In some major documents such as Nuremberg code and Helsinki declaration, the classical basis of ethical aspects of clinical practice is redefined with inevitable progress in medicine and commercialization. The importance of health-care morals in a specific nation is like the overarching laws. In addition, financial limitations and contemporary gregarious esteems regularly shape and decide ethical practice. The four basic standards of medical ethics (independence, justice, helpfulness, and nonperniciousness) frame the substructure for wellbeing experts to manage and choose what rehearses are moral in clinical settings. ${ }^{2,3}$ These basic ethical principles are grounded on the major documents of healthcare ethics (Hippocratic Oath, Nuremberg code, and Helsinki declaration). ${ }^{4}$ However, in spite of all these guidelines, there are still some incidents that give a detailed explanation about the unethical behaviour of medical students and health practitioners with patients as well as 
colleagues. ${ }^{5-7}$ This may be partly due to a demand of practical of good repute guidance from one end to the other in the information phase. Recently, In India, as the medical profession has been brought under "Consumer Protection Act," the complaints of poor ethical conduct against health-care practitioners have been increasing. ${ }^{8}$ This may be due to laxity in practices taken by the health-care professionals and increased public awareness. Sound development of ethical issues contributes to a top doctorpatient relationship and medical outcome. Studies from the South Asian countries quote chapter and verse that medical students require knowledge and achievement of institutional ethics panel and its corresponding role. ${ }^{9}$ Such studies would be pertinent to inspect ethical practices and refresh patient outcomes. An informed assent is a crucial tool of standard ethical medical practice. It is the practice of sharing information by all the patients that are essential to their flexibility to make pragmatic choices among infinite options in their perceived marvelous interest. ${ }^{10} \mathrm{It}$ is universally recognized as an essential safeguard to secure the safety of an individual's rights. ${ }^{11}$ Informed consents, which are generally provided in all health assistance environments including dental clinics, are a pertinent source of evidence to aid patients to figure informed decisions about their proposed treatment. ${ }^{12,13}$ The work of certain consents is rooted in moral, cultural, and legal principles. ${ }^{14,15}$ Informed consents are constantly perceived as inexorable for legal precaution against malpractice claims. ${ }^{16}$ The initial step is to explain the prevailing knowledge and therapy of health-care professionals in the frantic region. The present study was carried out to verify the level of knowledge, attitude, and practices toward bioethics among postgraduates at one of the well-known recognized medical institution.

\section{Objectives}

To assess the 'Knowledge, Attitude, and Practice' of postgraduate residents towards ethics in research.

\section{METHODS}

A cross-sectional study was conducted amongst the postgraduate students of the specialties present in KBN University-Faculty of Medical Sciences (Formerly known as KBN Institute of Medical Sciences) located in Kalaburagi (Formerly known as Gullbarga), Karnataka. After obtaining ethical clearance from the Institutional Ethical committee, the study was carried out over a period of three months from January 2020 to March 2020. A selfadministered pre-tested questionnaire was given to 40 postgraduate students selected on the basis of convenience sampling. In the first part of the questionnaire demographic details and year of the study was taken and the questionnaire consists of 15 questions related to knowledge and attitudes toward principles and practice of bioethics in clinical research, informed consent and role of the ethics committee in the institution. Among all the questions 5 are knowledge questions, 3 are attitude questions, and 7 are practice questions. It is the extent to which all of the items of a test measure the same latent variable. Descriptive statistics was used to analyse the results. The data was analysed and the percentage value was calculated for each. The data collected was condensed, a master chart was prepared by giving proper code words to ease the analysis. Microsoft Word and Microsoft Excel have been used to generate graphs, tables etc.

\section{RESULTS}

Figure 1 shows the distribution of male and female in the study population. Out of the total 40 subjects, $60 \%(n=24)$ were male and $40 \%(n=16)$ were female.

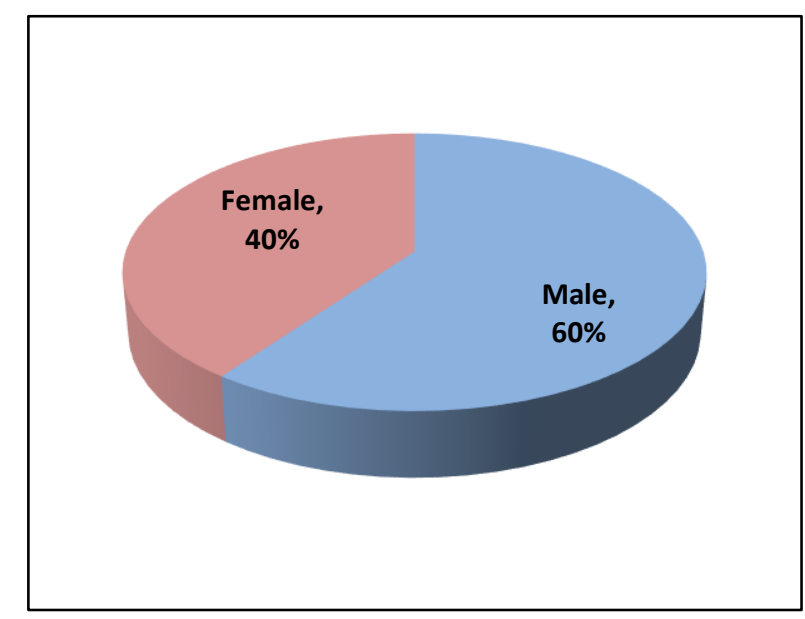

Figure 1: Distribution of study subjects according to gender.

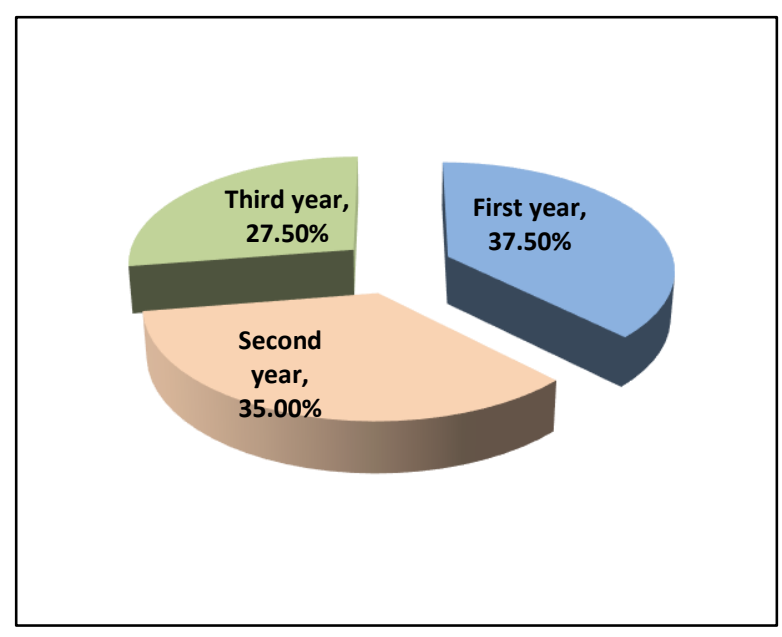

Figure 2: Distribution of study subjects according to year of study subjects.

Figure 2 represents the year wise distribution of study subjects 1st-year P.G's were 37.5\% $\left(\mathrm{n}_{1}=15\right)$, 2nd-year P.G's were $35 \%\left(\mathrm{n}_{2}=14\right)$, and 3rd-year P.G's were $27.50 \%$ $\left(\mathrm{n}_{3}=11\right)$.

Figure 3 explains the percentages of study subjects who have taken Hippocratic Oath after graduation, i.e., 70\% $(n=28)$ have taken the oath and rest was not. 


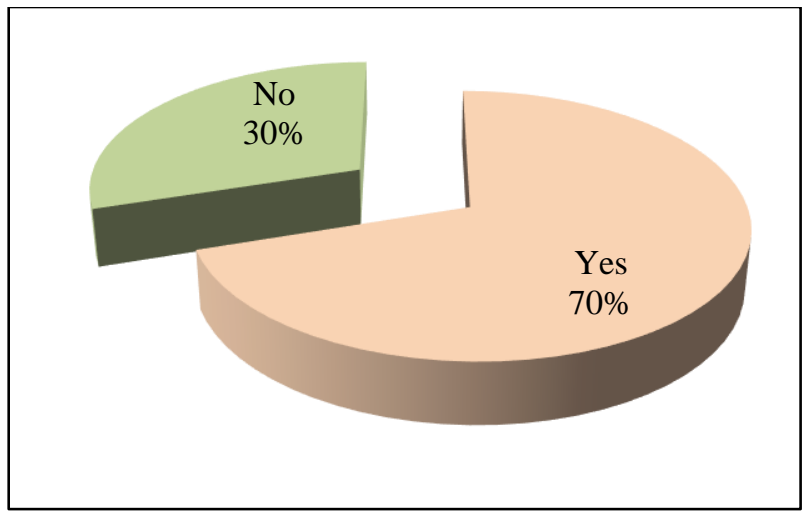

Figure 3: Percentage of study subjects who have taken Hippocratic Oath after graduation.

Figure 4 shows that majority (30\%) of the P.G's are getting knowledge of bioethics from books/journal, $20 \%$ are having from lectures in the departments, and $20 \%$ are obtaining it from the conference/symposiums/workshops, and the others are getting it from media and colleagues'.

Table 1 illustrates about knowledge, attitude, and practices of postgraduates regarding IEC. 85\% ( $\mathrm{N}=34)$ of total participants have awareness about IEC in the institution, of these majority are from final year followed by 2 nd year. $75 \%(\mathrm{~N}=30)$ of total participants submit the application to
IEC for review of research work, of these majority are from final year followed by 2 nd year. $60 \% \quad(\mathrm{~N}=24)$ of participants does not pursuance research work after rejection of their application. $37.5 \%(\mathrm{~N}=15)$ are aware regarding the composition of IEC. $65 \%(\mathrm{~N}=26)$ believe that the IEC of the Institution is playing its role properly. $72.5 \%$ $(\mathrm{N}=29)$ believe that there is a need for all studies involving human beings to be reviewed by IEC. 3rd-year P.G's have more knowledge regarding knowledge, attitude and practice regarding IEC.

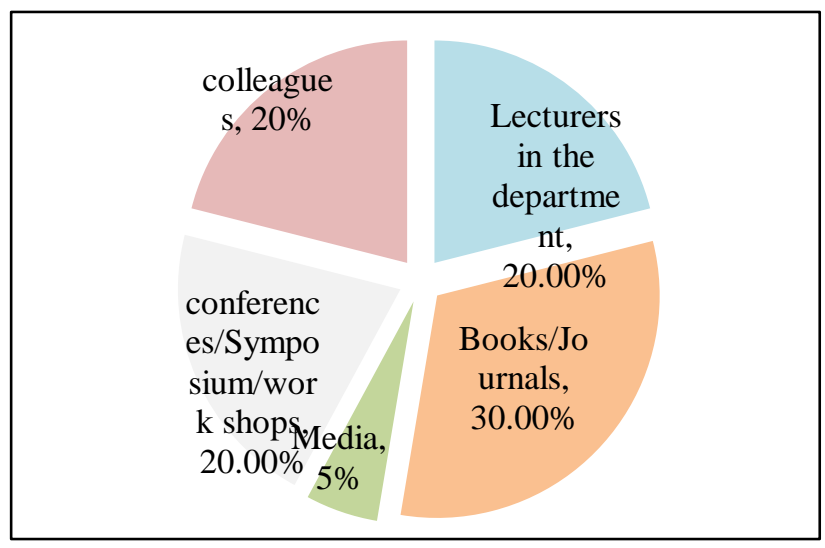

Figure 4: Source of knowledge of bioethics among postgraduates.

Table 1: Relationship between year of study subjects and knowledge, attitude, and practice regarding IEC.

\begin{tabular}{|c|c|c|c|c|}
\hline Questions regarding IEC & $\begin{array}{l}\text { 1st year } \\
n_{1}=15\end{array}$ & $\begin{array}{l}\text { 2nd year } \\
\mathrm{n}_{2}=14\end{array}$ & $\begin{array}{l}\text { 3rd year } \\
n_{3}=11\end{array}$ & $\begin{array}{l}\text { Total } \\
N=\left(n_{1}+n_{2}+n_{3}\right)=40 \\
(100 \%)\end{array}$ \\
\hline Awareness about the IEC in Institute & $11(73.33 \%)$ & $12(85.71 \%)$ & $11(100 \%)$ & $34(85 \%)$ \\
\hline $\begin{array}{l}\text { Submission of application to IEC for review } \\
\text { of research work }\end{array}$ & $6(40 \%)$ & $13(92.86 \%)$ & $11(100 \%)$ & $30(75 \%)$ \\
\hline $\begin{array}{l}\text { No pursuance of research work even after } \\
\text { rejection of the application }\end{array}$ & $4(26.67 \%)$ & $11(78.57 \%)$ & $9(81.81 \%)$ & $24(60 \%)$ \\
\hline $\begin{array}{l}\text { Awareness regarding the composition of } \\
\text { IEC }\end{array}$ & $3(20 \%)$ & $6(42.86 \%)$ & $6(54.55 \%)$ & $15(37.5 \%)$ \\
\hline $\begin{array}{l}\text { IEC of the Institution is playing its role } \\
\text { properly }\end{array}$ & $11(73.33 \%)$ & $9(64.23 \%)$ & $6(54.55 \%)$ & $26(65 \%)$ \\
\hline $\begin{array}{l}\text { Need of all studies involving human beings } \\
\text { to be reviewed by IEC }\end{array}$ & $6(40 \%)$ & $12(85.71 \%)$ & $11(100 \%)$ & $29(72.5 \%)$ \\
\hline
\end{tabular}

$\mathrm{N}=$ total study participants (PG's) from all the 3 years, $\mathrm{n}_{1}=1$ st year postgraduate participants, $\mathrm{n}_{2}=2$ nd year postgraduate participants, $\mathrm{n}^{3}=$ 3rd year postgraduate participants

Table 2: Relationship between the year of study and knowledge, attitude, and practice regarding informed consent.

\begin{tabular}{|lllll|} 
Questions regarding informed consent & $\begin{array}{l}\mathbf{1 s t} \text { year } \\
\mathbf{n}_{\mathbf{1}}=\mathbf{1 5}\end{array}$ & $\begin{array}{l}\text { 2nd year } \\
\mathbf{n}_{\mathbf{2}}=\mathbf{1 4}\end{array}$ & $\begin{array}{l}\text { 3rd year } \\
\mathbf{n}_{\mathbf{3}}=\mathbf{1 1}\end{array}$ & $\begin{array}{l}\text { Total } \\
\mathbf{N}=\left(\mathbf{n}_{\mathbf{1}}+\mathbf{n}_{\mathbf{2}}+\mathbf{n}_{\mathbf{3}}\right)=\mathbf{4 0} \\
(\mathbf{1 0 0} \%)\end{array}$ \\
\hline $\begin{array}{l}\text { Taking of written informed consent in } \\
\text { research work }\end{array}$ & $6(40 \%)$ & $11(78.57 \%)$ & $11(100 \%)$ & $28(70 \%)$ \\
\hline $\begin{array}{l}\text { In local language } \\
\text { According to the format of ICMR }\end{array}$ & $5(33.33 \%)$ & $11(71.42 \%)$ & $\begin{array}{l}10 \\
(90.90 \%)\end{array}$ & $26(65 \%)$ \\
\hline
\end{tabular}

Continued. 


\begin{tabular}{|lllll|}
\hline Questions regarding informed consent & $\begin{array}{l}\text { 1st year } \\
\mathbf{n}_{1}=\mathbf{1 5}\end{array}$ & $\begin{array}{l}\text { 2nd year } \\
\mathbf{n}_{2}=14\end{array}$ & $\begin{array}{l}\text { 3rd year } \\
\mathbf{n}_{3}=11\end{array}$ & $\begin{array}{l}\text { Total } \\
\mathbf{N}=\left(\mathbf{n}_{1}+\mathbf{n}_{2}+\mathbf{n}_{3}\right)=40 \\
(\mathbf{1 0 0} \%)\end{array}$ \\
\hline $\begin{array}{l}\text { Provide a copy of written informed consent } \\
\text { to the patients }\end{array}$ & $2(13.33 \%)$ & $7(50 \%)$ & $7(63.64 \%)$ & $16(40 \%)$ \\
\hline
\end{tabular}

$\mathrm{N}=$ total study participants (PG's) from all the 3 years, $\mathrm{n}_{1}=1$ st year postgraduate participants, $\mathrm{n}_{2}=2$ nd year postgraduate participants, $\mathrm{n}_{3}=$ 3rd year postgraduate participants

Table 2 exemplifies the knowledge, attitude, and practices of postgraduates regarding informed consent. $70 \%(\mathrm{~N}=28)$ declared that they have taken the written informed consent in their research work and that to $65 \%(\mathrm{~N}=26)$ has taken in the local language. $57.5 \%(\mathrm{~N}=23)$ of the postgraduate have taken it according to the ICMR format but only $40 \%$ $(\mathrm{N}=16)$ of the $\mathrm{PG}$ 's gave a copy of the written informed consent to their patients.

\section{DISCUSSION}

The very important thing that people who conduct research or use and apply research results must know the contents of ethical research. The researchers should have contemporary knowledge about the policies and procedures that are designed to ensure the safety of research subjects and to prevent sloppy research. The ignorance of policies that are designed to protect research subjects is not considered as a viable excuse for ethically questionable projects. Hence, it is the responsibility of the researcher to fully understand the policies and theories that are designed to upright research practices.

In our study, the larger part of the participants were male when contrasted with females, this distinction might be expected as the greater part of the male is joining P.G after their U.G; however, females are not proceeding with their studies after U.G because of some societal reasons. Year wise distribution of study participant was all most equal in every year because the number of P.G seat will remain the same in the college, but in our study which was based on convenient sampling had majority from 1st year.

In our study, the percentage of students who take formal Hippocratic Oath after U.G course is $75 \%$. However, in the study done by Mohammad et al only $22.2 \%$ of the residents and $47.1 \%$ of the faculty have formally taken Hippocratic Oath. ${ }^{17} 85 \%$ of the P.G students are aware of the IEC in the institution. Most of them are final year P.G's because they have undergone synopsis submission they will have work with the IEC. Most of the PG's are submitting the application to IEC for review of their research work; a majority of them are 3rd-year P.G's. This may be because the final years need article publication; many journals accept the articles when there is an IEC clearance certificate. Completion of research work even after rejection of application was very less, these results are in contrast with the Nadig et al study done in $2011 .{ }^{18} 65 \%$ are opined that IEC of the institution is playing its role properly. $72.5 \%$ does acknowledge that there is a need for all studies involving human beings to be reviewed by IEC. There is a critical connection between the year of study subjects and information, state of mind, and work on with respect to IEC, the final year PG's are more mature and everyone believes that every study needs to be reviewed by IEC, while first year PG's have a varying opinion, only $40 \%$ of the first year PG's believe that review by IEC is essential.

$70 \%$ are having the habit of taking a written informed agreement. $65 \%$ of the P.G's said that they are taking permission in the local language, but only $57.5 \%$ of them were obtaining according to the ICMR guidelines. $40 \%$ has provided a copy of the written informed agreement to the patients. The connection between a year of study and information, state of mind and work on with respect to educated assent is high in 3rd year when contrasted with 2nd year and 1st year. Occupants knowledge and states of mind toward well-being research enhance essentially with expanding year of study which is like the investigation conducted by Khan et al. ${ }^{19}$ Significant relationship is seen only with the habit of taking a written, composed consent and taking consent in the regional language. However, the present results are in contrast with the Mohammad et al study. ${ }^{17}$

Mohammad et al announced that curricular preparing with respect to bioethics is either deficient or insufficient as department teachers are not assuming an essential part and are not favouring the method of learning. ${ }^{20}$ This finding was like the present study. In the study done by Adhikari et al, a significant number of the specialists opined that they are looking for learning of morals from lectures and nurses believe that from journals and books. ${ }^{21}$ The study was done by Chopra et al also highlighted gaps in the knowledge about practical aspects of health-care ethics among physicians and nurses which they encounter in day-to-day practice at the workplace. ${ }^{22}$

\section{Limitations}

The institute in which the study was conducted is a start-up for post graduate intake. Hence it has only few post graduates in selected departments. Also, among those all the post graduates had not volunteered for their participation.

\section{CONCLUSION}

Health professionals, very frequently come across ethical dilemmas in their day-to-day practice. They are not provided formal training in practical aspects of ethics in their curriculum. To overcome this, emphasis should be given to postgraduate training on legal jurisprudence, and 
legal medicine as this is essential for the medicos to protect themselves from civil litigation (trespass, assault, or battery) and even criminal proceedings for common aggravated or indecent assault. In the present study, departmental lectures are not preferred a mode of learning. Hence, there is an urgent need to include practical education of ethics to bridge the gap in the knowledge, attitude, and practices regarding ethics in clinical practice and research. It should be remembered that the profession exists as long as it enjoys the trust of the society, and this can be assured by always placing the interest of the patient above one's own interest.

\section{ACKNOWLEDGEMENTS}

The authors would like to thank the study participants for their participation and kind cooperation throughout the study.

\section{Funding: No funding sources}

Conflict of interest: None declared

Ethical approval: The study was approved by the Institutional Ethics Committee

\section{REFERENCES}

1. Hiremath S. Textbook of Public Health Dentistry. 3rd ed. New Delhi: Elsevier India. 2016.

2. Summers J. Principles of Healthcare Ethics. In: Morrison EE, Furlong E. Health care ethics: critical issues for the 21st century. 4th ed. Burlington, Mass: Jones \& Bartlett Learning. 2019;41-56.

3. Beauchamp T, Childress J. Principles of biomedical ethics. 8th ed. New York, NY: Oxford University Press. 2019.

4. Adhikari S, Paude K, Aro AR, Adhikari TB, Adhikari B, Mishra SR. Knowledge, attitude and practice of healthcare ethics among resident doctors and ward nurses from a resource poor setting, Nepal. BMC Med Ethics. 2016;17(1):68.

5. Green MJ, Farber NJ, Ubel PA, Mauger DT, Aboff BM. Lying to each other: When internal medicine residents use deception with their colleagues. Arch Intern Med. 2000;160:2317-23.

6. Baldwin DC Jr., Daugherty SR, Rowley BD, Schwarz MD. Cheating in medical school: A survey of second year students at 31 schools. Acad Med. 1996;71(3):267-73.

7. Baldwin DC Jr., Daugherty SR, Rowley BD. Unethical and unprofessional conduct observed by residents during their first year of training. Acad Med. 1998;73(11):1195-200.

8. The Consumer Protection Act; 1986. www. consumervoice.org. Accessed on 18th June, 2021.
9. Chatterjee B, Sarkar J. Awareness of medical ethics among undergraduates in a West Bengal medical college. Indian J Med Ethics. 2012;9(2):93-100.

10. Andre J. Bioethics as Practice. Chapel Hill: University of North Carolina Press. 2002.

11. Informed Consent: Maintaining a Clinical Perspective. In: Simon R. Clinical psychiatry and the law. 2nd ed. Washington, D.C.: American Psychiatric Press. 1992.

12. Worthington R. Clinical issues on consent: Some philosophical concerns. J Med Ethics. 2002;28(6):377-80.

13. Dierks MM, Sands DZ, Safran C. Re-engineering the Process of Surgical Informed Consent. Proceeding AMIA Symposium. 1999;731-5.

14. Jefford M, Moore R. Improvement of informed consent and the quality of consent documents. Lancet Oncol. 2008;9(5):485-93.

15. Faden RR, Beauchamp TL, King NM. A History and Theory of Informed Consent. New York: Oxford University Press. 1986.

16. Meisel A, Kuczewski M. Legal and ethical myths about informed consent. Arch Intern Med. 1996;156(22):2521-6.

17. Mohammad M, Ahmad F, Rahman SZ, Gupta N, Salmanet T. Knowledge, attitudes and practices of bioethics among doctors in a tertiary care government teaching hospital in India. J Clin Res Bioethics. 2011;2(6):1-5.

18. Nadig P, Joshi M, Uthappa A. Competence of ethics committees in patient protection in clinical research. Indian J Med Ethics. 2011;8(3):151-4.

19. Khan H, Khan S, Iqbal A. Knowledge, attitudes and practices around health research: The perspective of physicians in training in Pakistan. BMC Med Educ. 2009;9(1):46.

20. Mohammed AM, Ghanem MA, Kassem AA. Knowledge, perceptions and practices towards medical ethics among physician residents of university of Alexandria hospitals, Egypt. East Mediterr Health J. 2012;18(9):935-45.

21. Adhikari S, Paudel K, Aro AR, Adhikari TB, Adhikari B, Mishra SR. Knowledge, attitude and practice of health care ethics among resident doctors and ward nurses from a resource poor setting, Nepal. BMC Med. Ethics 2016;17(1):68.

22. Chopra M, Bhardwaj A, Mithra P, Singh A, Siddiqui A, Rajesh DR. Current status of knowledge, attitudes and practices towards healthcare. Ethics among doctors and nurses from Northern India-a multicentre study. J Krishna Inst Med Sci Univ. 2013;2(2):102-7.

Cite this article as: Ahmed MM, Saba S. A questionnaire based institutional assessment of 'knowledge', 'attitude' and 'practice' about bioethics in clinical research among postgraduate residents. Int J Basic Clin Pharmacol 2021;10:920-4. 